\title{
Modernisation of production as a factor of influence on economic stability of the industrial enterprise
}

\author{
N.Yu. Varkova ${ }^{1, *}$ \\ ${ }^{1}$ South Ural State University, Chelyabinsk, Russia
}

\begin{abstract}
The present article considers key problems of modernising production process at industrial enterprises, also referred to as reengineering, in modern conditions of Russian economics. Having analysed factors that affect operation of business, the author presents the model of interdependence between modernisation of production and sustainable development of the enterprise. Based upon analysis of Russian and foreign sources there were formulated fundamentals of the modernisation process and presented an algorithmic mechanism of enabling modernisation at the industrial enterprise. The said mechanism takes into account main aspects of sustainable development of the industrial enterprise and evaluation parameters as to the modernisation efficiency.
\end{abstract}

\section{Introduction}

In modern ever-changing conditions when competition is getting stronger and stronger, and there act environmental factors that bring influence on the enterprise activities, coping with different types of crisis, inhibiting bankruptcy, and also planning measures intended to achieve a steady sustainable development are seen as a recently established business priority of industrial enterprises. In this context it has become urgent to design a system of modernisation of industrial production understood as a process comprising investment, innovation and other constituents related to the sustainable development process.

In economic science the notion of modernisation represents evolution and renovation in technological and social development of the society, both in global scale and at the level of a particular country, branch or business enterprise [1]. This process involves enhancing properties of the production system and its separate components, using investment resources, and selecting criteria of economic efficiency, which serve as a ground for making decisions on production processes improvements. Thus, we can detect interrelations and mutual influences between the production modernisation process and economic stability of the business enterprise.

According to Rosstat (Federal State Statistics Service), as of today the average age of machinery and equipment in Russia is about 11.2 years [2]. This situation is mainly accounted for imports. For example, the share of imports in machine-tool industry is more than $90 \%$, in heavy machine-building $-60-80 \%$, in electronics manufacturing industry - about $80-90 \%$. It implies that the ability to maintain the technological level of Russian economics to a great extent depends on imported services (servicing and repair) and on substitutions from abroad due to moral and physical depreciation of equipment and associate technologies [3]. A number of countries stiffened sanctions against Russia after it joined Crimea in March 2014 and in connection with the political crisis in Ukraine. As a result, domestic industries are facing enormous challenges, which include the risk to lose an access to western technologies and cooperation with foreign investors, and to deal with limitations on purchasing import equipment and complementary parts. The Government of the Russian Federation adopted regulations aimed to reject imported equipment and to introduce the policy of import substitution. Presently there has been composed a list of goods to be purchased only from manufacturers of Russia, Byelorussia and Kazakhstan [3].

In order to cope with these challenges, it is necessary to build up systems designed to facilitate modernisation, project and technological activity of the industrial enterprise, as well as the system aimed to manage scientific and technological reproductive performance, innovational, educational, and scientific processes that take place inside the enterprise and in association with other market participants $[4,5]$.

\section{Theoretical framework and literature review}

Issues connected with managing modernisation of production at the industrial enterprise and related interactions have been examined by many Russian academic economists such as T.Yu. Bazarov, V.P. Barancheev, V.V. Glukhov, V.E. Dementiev, S.B. Korobko, V.K. Lozenko, E.V. Popov, A.M. Permyakov, L.P. Kleeva, G.B. Kleine, V.A. Balukova, Yu.V.

Corresponding author: Varkovan80@mail.ru 
Levitsky, I.I. Mazur, I.A. Sadchikov, V.D. Shapiro and other scientists.

Questions of reengineering, production modernisation and a business enterprise are examined in works of such western authors as I. Ansoff, S. Beer, K. Blanchard, T. Vaghorn, P. Drucker, S. Klein, N. Rosenberg, D. Sahal, R. Foster, M. Hammer, J. Champy and others.

Sustainable development and stability of economic systems are subject of theoretic and practical research conducted and presented in scientific papers of such foreign and Russian scholars as J.L. Laft, M. Robson, J. Schumpeter, J. Haywood, D.R. Ageeva, A.V. Bezgodov, O.V. Bratkov, L.V. Volkova, D.S. Kondaurova, A.G. Koryakov, O.V. Mikhalev, V.M. Tumin, A.D. Sheremet, E.M. Korotkov, T. Sukhorukov.

Analysis of prominent papers on the given research issue shows that lately there has been developed a set of approaches to managing the production modernisation at the industrial enterprise, and there has been specified its impact on economic stability and development of production systems without recessions. It should be noted that these matters are still conventionally considered in the frame of the approach based on designing such a system of measures that shall enable an industrial enterprise to surmount the crisis, while modernisation of production must prevent recessions, rather than facilitate overcoming them when they already happen. Therefore it is essential to specify the very notion of modernisation of production and its influence on the economic stability of the industrial enterprise.

The object of the research: reengineering (modernisation) of the industrial enterprise and the extent of its influence on the enterprise.

The goal of the article is to develop the model that will reveal the influence of reengineering production on economic stability of the industrial enterprise.

\section{Materials and methods}

\section{A. Description of methods}

At the present stage of economic evolution it is common to determine if the industrial enterprise has achieved stability or not. It is defined by positive dynamics of quantitative and qualitative transformations of elements and business processes at different stages of its life cycle $[8,9]$. Such transformations include renovation of production facilities, launching a new product, modernising and reengineering the technological base. Accordingly, the efficiency of sustainable development in many ways is defined by the level of investment and innovation potential of the enterprise, serving as the key factor [10]. Any industrial enterprise is an open dynamic system, since it constantly interacts with external environment, which is susceptible to significant fluctuations. From external environment the industrial enterprise receives resources in the form of raw materials and supplies, fuel and energy, capital and information, labour force, equipment and other assets that are becoming part of its internal environment. Partly resources are processed, converted into products and services, which return to external environment [6,7]. In the course of implementing modernisation projects aimed to maintain financial stability of the industrial enterprise, there arises a necessity to consider its risk profile in order to ensure fast response to external and internal threats.

It is essential that managers of the enterprise apply a certain mechanism designed to facilitate modernisation. The principal element of the said mechanism is to determine the direction of modernisation, which would enable sustainable development. This mechanism represents the process of implementing the production modernisation as a sequence of specific stages. Each stage involves evaluation and analysis of certain economic activity parameters of the industrial enterprise.

The designed mechanism allows to achieve a prescribed pace of sustainable development on the basis of an integrated approach to modernisation of the industrial enterprise.

In view of sustainable development being an integrated complex with a definite structure and also a process influenced by a great number of factors, the author offers a special algorithm that will aid to assess the level of the development stability based on using modernisation methods. The offered algorithm can include a sequence of the following principal stages:

1) Analysis and forecasting stage. It involves identification and analysis of principal technological aspects of the business operation. This stage presents conducting a technological audit and analysis of production facilities. Energy efficiency, ecological parameters, flexibility, automation of production, as well as parameters of launching new products are to be assessed at this stage. Key factors of external environment of the enterprise are subjected to analysis.

2) Estimating and forecasting stage. At this stage indices of sustainable development of the industrial enterprise are built up. Top managers shall estimate efficiency of core activities, analyse the revenue structure and assets of the enterprise, structure of borrowed funds, net profit, and to specify the return on assets.

3) Formation stage. This stage of the mechanism involves identifying such directions of modernisation that will provide for sustainable development of the enterprise.

4) Control and adjusting stage. It implies comparison of planned results against standard indicators, as well as launching feedback mechanism.

\section{B. Graphic model of implementing modernisation}

The model of the mechanism aimed to enable modernisation of the industrial enterprise presents a system of main criteria that affect its economic stability. Fundamental provisions of modernisation are as follows. External environment of the industrial enterprise is characterised by a great number of highly volatile parameters, and in such conditions the enterprise has to respond really fast. It implies objective complexity of achieving sustainable development [11]. 
Analysis of external environment of the enterprise should include investigation of such key factors (factors of direct impact) as politics and economics influences, impact made by competitors, product consumers, suppliers, resources and materials, as well as sociocultural factors. When making an analysis of internal environment of the enterprise, it is essential to distinguish three groups of principal influencing aspects, namely, technical (production and technological parameters, indicators of mastering new products, of automation, ecological properties), economic (investments, ratio of spending resources), organisational (attributes of the enterprise staff, management methods and styles, their efficiency).

The model of mutual influences of modernisation and sustainable development is graphically presented in Fig.1.

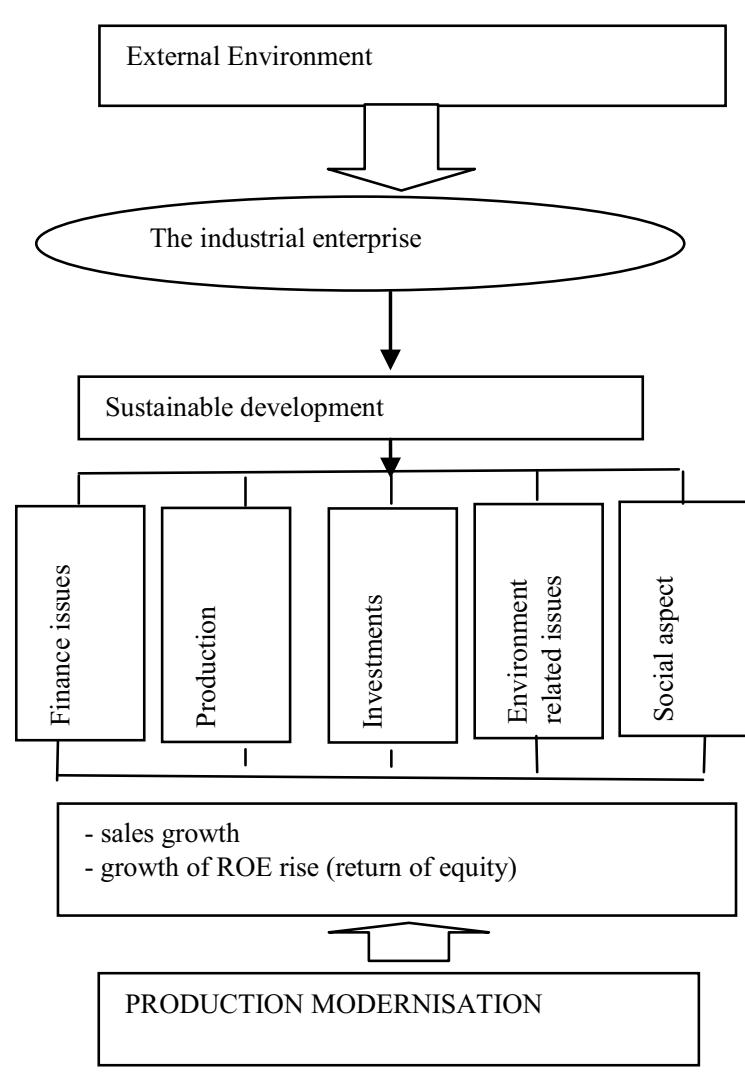

Fig. 1. Graphic Model of mutual influences of sustainable development and production modernisation.

Sustainable development can be considered as a process specified by enhanced economic efficiency indices, technological efficiency and quality of production. To improve indices of economic efficiency and technical excellence is possible by means of preparing a strategic plan of complex modernisation. The continuity of the modernisation process is to be provided by relevant elements of the organisational structure of management implemented at the industrial enterprise.

Below we present the model of the mechanism aimed to enable modernisation at the industrial enterprise. The present model testifies that the functioning of the industrial enterprise depends upon an impact of factors of external and internal environment. When analysing the enterprise operations, it is also necessary to bear in mind the impact made by basic indices of sustainable development and effectiveness criteria applied to production modernisation [12].

The presented mechanism enables top managers of the enterprise to consider all aggressive and most disturbing influences when performing the process of complex modernisation of production, as well as to analyse how these influences are reflected in sustainable development of the industrial enterprise $[13,14]$.

\section{Economic and Mathematical Model}

One of principal factors of the effective functioning of any enterprise in competitive conditions is how timely and adequately it reacts to changes of external environment that create a situation, in which decisions are made under risk. In this context evaluation of possible risks and risk management becomes a key issue of strategic management, and, therefore, of corporate planning.

Hence, risk management in performing the process of production modernisation is one of core directions of the corporate planning, since in this very aspect there arises a risk of making non-optimal solutions $[17,18]$.

We offer an approach to evaluation of strategic risk based on applying such an integral index as a riskbenefit ratio. It implies that the risk level is measured by correlation of the anticipated profit and anticipated loss when comparing different variants of modernisation strategies (1).

$$
K \mathrm{i}=Z \mathrm{i} / R \mathrm{i},
$$

where $K \mathrm{i}$ is a risk-benefit ratio of the strategy variant $\mathrm{i}$; $\mathrm{Zi}$ is an anticipated profit of the strategy variant $\mathrm{i} ; R \mathrm{i}$ is an anticipated loss of the strategy variant $i$. The riskbenefit ratio $K$ i demonstrates what income falls within one rouble of loss.

\section{Conclusions}

By this means, within the framework of the presented concept of sustainable development, operation of the industrial enterprise ceases to be an uncontrolled, spontaneous process, and becomes self-organised. The control mechanism has complex nature, it is designed to achieve new strategic goals and to facilitate stability at all life-cycle stages.

The interrelation between the process of production modernisation and sustainable development presented in the article can be also viewed at the level of the indices that characterise the given processes. Indicators of modernisation efficiency include: net profit margin; turnover rate of the total assets; equity capital; productivity of labour; assets value; capital productivity and equipment productivity ratio; cost of production of sold goods $[5,19]$.

Indicators of sustainable development of the enterprise include: the coefficient of stable economic 
growth; profitability of sales; turnover rate of productive assets; profitability of production assets; the financial lever effect; the equity capital level; profitability of production assets; return on assets against the net profit $[5,20]$.

The article presents the model of correlation between sustainable development of the industrial enterprise and modernisation of production. The author offers the mechanism aimed to enable modernisation of production at the industrial enterprise. Applying the given mechanism, managers of the enterprise can make a management decision on selecting a direction of modernisation, and, accordingly, on selecting the strategy required to implement it and to achieve sustainable development of the industrial enterprise.

The work was supported by Act 211 Government of the Russian Federation, contract № 02.A03.21.0011

\section{References}

1. N.A. Dubrovina, Finance and Credits, 3, 21 (2014)

2. I.V. Krasnopevtseva, Economics and Management in Machine-Building Industry, 6, 21 (2012)

3. Rosstat: information and analytical materials. Electronic data. Moscow (2016). http://www.gks.ru/wps/wcm/connect/rosstat_main/r osstat/ru/statistics/science_and_innovations/science/

4. A.O. Kalabaeva, Ekonominfo, 17, 9-13 (2012)

5. K.P. Lichko, M.A. Romanyuk, E.I. Krivomaz, Herald of Moscow State Academy of Business Administration. Series: Economics, 2(22), 121-132 (2013)

6. R.A. Fatkhutdinov, Production Engineering (INFRA-M, Moscow, 2000)

7. R.A. Fatkhutdinov, Management of the Organisation Competitiveness (EKSMO, Moscow, 2004)
8. T.A. Khudyakova, A.V. Shmidt, Proc. of The 26th International Business Information Management Association Conference, 1617-1625 (2015)

9. T.A. Khudyakova, A.V. Shmidt, Proc. of The 26th International Business Information Management Association Conference, 1607-1611 (2015)

10. T.A. Khudyakova, Proc. of the International Congress on Interdisciplinary Behavior and Social Science, 292-294 (2015)

11. T.A. Khudyakova, Proc. of the International Congress on Interdisciplinary Behavior and Social Science, 295-297 (2015)

12. T.A. Khudyakova, A.V. Shmidt, Proc. of The 26th International Business Information Management Association Conference, 1626-1634 (2015)

13. T.A. Khudyakova, Actual problems of economics, 12, 444-450 (2015)

14. T.A. Khudyakova, A.V. Shmidt, Proc. of The 26th International Business Information Management Association Conference, 1612-1616 (2015)

15. D.R. Kondaurova, Proc. Economics, Management, Finance: Materials of the II International Scintific Conference, 130-132 (2012)

16. N.V. Rodionova, Crisis Management (Publishing House UNITY, Moscow, 2012)

17. Yu.I. Ryzhikov, Simulation Modelling. Theory and Technologies (Publishing House "Korona Print", St.-Petersburg, 2004)

18. V. Zhukov, Finances Business, 8, 18-21 (1996)

19. A.G. Aganbegyan, Money and Credits, 3, 4, (2010)

20. A.S. Pelikh, Organisation of Entrepreneurial Activity (Publishing and Scintific Centre MarT, Rostov-on-Don, 2015). 